\title{
Partisipasi Masyarakat Tionghoa dalam Pelaksanaan Musrenbang Pada Kelurahan Sukadamai Kecamatan Medan Polonia
}

\section{Chinese Community Participation in the Implementation of Musrenbang in Sukadamai Village, Medan Polonia District}

\author{
Muhammad Adi Kurniawan, Badaruddin \& Humaizi \\ Program Studi Magister Studi Pembangunan, Fakultas Ilmu Sosial dan Ilmu Politik, \\ Universitas Sumatera Utara, Indonesia
}

Diterima:01 Oktober 2020; Disetujui: 15 Desember 2020; Dipublish: 31 Januari 2021

\begin{abstract}
Abstrak
Penelitian ini berjudul Partisipasi Masyarakat Tionghoa dalam Pelaksanaan Musrenbang Pada Kelurahan Sukadamai. Penelitian ini bertujuan untuk menganalisa proses partisipasi masyarakat etnis Tionghoa dalam Musrenbang di Kelurahan Sukadamai, Kec Medan Polonia dan memahami bentuk-bentuk partisipasi masyarakat etnis Tionghoa dalam Musrenbang di Kelurahan Sukadamai, Kec Medan Polonia. Teori yang digunakan dalam penelitian ini adalah teori partisipasi. Metode yang dilakukan adalah dengan menggunakan analisis data kualitatif. Teknik pengumpulan data yang digunakan dalam penelitian ini adalah observasi, wawancara dan studi kepustakaan. Proses Musrenbang Kelurahan Sukadamai Kecamatan Medan Polonia terdiri dari Pra-persiapan, Pelaksanaan dan Penutupan dan dalam setiap tahapan ini, masyarakat Etnis Tionghoa terlibat aktif. Bentuk-bentuk partisipasi masyarakat, maka Etnis Tionghoa dalam Musrenbang Kelurahan Sukadamai Kecamatan Medan polonia meliputi; pikiran, tenaga, keahlian, barang dan uang.
\end{abstract}

Kata Kunci: Kualitatif, partisipasi, Tionghoa.

\section{Abstract}

The title of this research is Participation of Chinese Society in the Implementation of Musrenbang at Sukadamai Village. This research aims to analyze the participation process of the Chinese ethnic community in the Musrenbang in Sukadamai Village, Medan Polonia District and tounderstand the forms of participation Chinese ethnic society in the Musrenbang in Sukadamai Village, Medan Polonia District. Theory in this research used theory of participation. The method used is qualitative data analysis. The data collection techniques are observation, interviews and literature study. The Musrenbang process of Sukadamai Village, Medan Polonia District consists of Pre-preparation, Implementation and Closing and in each of these stages, the Chinese ethnic society is actively involved. Forms of community participation, the Chinese ethnic in the Musrenbang of Sukadamai Village, Medan Polonia District include; thoughts, energy, expertise, goods and money.

Keywords: Qualitative, participation, Chinese.

How to Cite: Kurniawan, M.A. Badaruddin. \& Humaizi. (2021). Partisipasi Masyarakat Tionghoa dalam Pelaksanaan Musrenbang Pada Kelurahan Sukadamai Kecamatan Medan Polonia. PERSPEKTIF, 6 (2): 118-229

\footnotetext{
*Corresponding author:

E-mail: adikurniawan@gmail.com
}

ISSN 2085-0328 (Print)

ISSN 2541-5913 (online) 


\section{PENDAHULUAN}

Partisipasi pembangunan di Indonesia sangat mutlak dibutuhkan Sebab pembangunan yang berbasiskan masyarakat menjadi tolak ukur keberhasilan pembangunan dalam kehidupan berbangsa dan bernegara. Sebagaimana dijelaskan oleh Amartya Sen, bahwa pembangunan harus memberikan ruang demokratisasi bagi masyarakat. Artinya kesempatan masyarakat untuk pembangunan menjadi kunci keberhasilan suatu pembangunan. Adapun pengertian partisipasi pembangunan kegiatan warga negara biasa dalam mempengaruhi proses pembuatan dan pelaksanaan kebijaksanaan umum dan dalam ikut menentukan pemimpin pemerintahan (Surbakti, 1992).

Setiap warga negara yang ikut berpartisipasi memiliki berbagai macam maksud dan tujuan yang masing-masing ada pada diri setiap individu, dikarenakan dengan mengikutsertakan dirinya dalam kegiatan politik sekecil apapun yaitu salah satunya dengan melakukan partisipasi politik tentu saja sudah timbul dalam diri setiap warga negara akan kesadaran politik dalam dirinya. Setiap warga negara Indonesia mempunyai hak serta kewajiban untuk terlibat aktif dalam pembangunan di Indonesia baik dalam tahapan perencanaan, pelaksanaan, pengawasan serta evaluasi (Mulyadi, 2012; Akbar, 2018; Karwur, 2016; Arnstein, 1969). Partisipasi masyarakat dalam pembangunan di Indonesia mempunyai kedudukan yang sama tanpa memandang suku, agama, ras maupun golongan. Sejak reformasi 1998, telah memberi ruang kebebasan kepada seluruh masyarakat untuk berpartisipasi dalam pembangunan. Presiden Abduraman Wahid alias Gusdur mengeluarkan kebijakan PP No. 6 Tahun 2000 yang bertujuan menghapuskan diskriminasi terhadap kaum minoritas etnis Tinghoa di segala bidang termasuk peranannya dalam pembangunan.

Etnis Tionghoa merupakan etnis yang berasal dari Tiongkok yang menetap dan menjadi warga Indonesia. Etnis tionghoa salah satu Etnis yang memiliki ciri khas sangat kuat dan dapat langsung dikenali dari bahasa, budaya, dan ciri fisik yang sangat signifikan. Generasi pertama etnis Tionghoa berasal dari pelabuhan Xianmen Provinsi Fujian yang berlayar menuju Singapore dan Indonesia untuk mencari kehidupan yang lebih baik (Tan, 2012).

Pada saat itu mereka hidup hanya sebagai kuli, buruh, tukang air dan sebagai pedagang kecil. Namun setelah beberapa tahun mereka berhasil melakukan pembangunan dan perubahan, diantaranya mereka berhasil menjadi pengusaha dan banker ternama di Indonesia, disebut lima nama sebagai konglomerat yang meguasai perekonomian Indonesia saat ini, yaitu Liem Sioe Liong, Eka Tjipta Widjaja, Mochtar Riaddy, Suhardi Gondookusumo, dan Projogo Pangestu (Lubis, 2010).

Berbagai survei ekonomi menjelaskan bahwa warga Tionghoa menguasai $70 \%$ perekonomian Indonesia. Warga Tionghoa terbilang sukses dalam bidang ekonomi. Namun dalam kehidupan sosial mereka sangat tertutup dengan etnis lainnya. Bisa dilihat dari dinamika yang masih terjadi, warga Tionghoa lebih senang tinggal berkelompok pada etnisnya saja, tidak hanya tempat tingggal bahkan sekolah untuk anak warga etnis Tionghoa (Mahmud, 2013).

Salah-satu yang menarik untuk diperhatikan partisipasi masyarakat Etnis Tionghoa dalam pembangunan adalah fase Musyawarah Rencana Pembangunan atau disingkat Musrenbang. Musrenbang adalah forum antarpelaku dalam rangka menyusun rencana pembangunan Nasional dan rencana pembangunan Daerah. Musrenbang diatur dalam Undang-Undang no. 25 tahun 2004 tentang Sistem Perencanaan Pembangunan Nasional dan diatur oleh Menteri Perencanaan Pembangunan Nasional/Bappenas untuk tingkat nasional dan Badan Perencanaan Pembangunan Daerah (Bappeda).

Musrenbang adalah sebuah mekanisme yang benar-benar menjadi wadah dalam mempertemukan apa yang dibutuhkan masyarakat dan bagaimana pemerintah merespon hal tersebut, sehingga pemerintah juga tahu apa yang sebenarnya yang masyarakat butuhkan. Dari semua elemen termasuk warga Tioghoa harus ikut dari tahapan proses, penentuan dan pelaksanaan secara bersama memikirkan bagaimana membiayai dan mengimplementasi hasil musrenbang.

Sementara itu, Musrenbang ada beberapa fase tingkatan yaitu Murenbang RT, Musrenbang RW (Rembug RW), Musrenbang 
Desa/Kelurahan, Musrenbang Kecamatan, Musrenbang Kota, Musrenbang Provinsi dan terakhir Musrenbang Nasional. Musrenbang ini diselenggarakan untuk membahas tentang prioritas kegiatan pembangunan dan pengalokasian anggaran. Musrenbang juga menjadi wadah penyusunan dokumen rencana pembangunan dan koordinasi antara instansi pemerintah dan partisipasi seluruh pelaku pembangunan.

Partisipasi itu sendiri merupakan suatu konsep yang merujuk pada keikutsertaan seseorang dalam perencanaan pembangunan dan berbagai aktivitas pembangunan. Pembangunan tidak akan bermakna tanpa adanya dukungan dan partisipasi dari masyarakat setempat (Suharyanto, 2014; Darmila dkk., 2019; Kusmanto, 2013). Karena masyarakat lebih mengetahui kebutuhan dan potensi yang ada di daerah tersebut. Namun dalam mewujudkan partisipasi pada masyarakat itu sendiri bukan hal yang mudah bagi pemerintah, Karena di dalam satu daerah itu sendiri terdapat masyarakat yang beragam. Desentralisasi di tingkat Kabupaten menjadi satu cara agar pemerintah lebih dekat dengan masyarakat sehingga lebih tahu kepentingan dan kebutuhann masyarakat (Suharyanto, 2016; Zega dkk., 2018).

Pada Kelurahan Sukadamai, Kecamatan Medan Polonia masyarakatnya didominasi mayoritas entis Tonghoa. Pada masa Orde baru Soeharto, Etnis Tionghoa Sukadamai masih mengalami diskrimnasi di bidang politik. Etnis Tionghoa tersebut masih belum dilibatkan sama sekali dalam Musrenbang. Etnis Tionghoa Sukadamai hanya sebatas fokus menjalankan usaha ekonomi. Namun semenjak masa reformasi, Etnis Tionghoa mulai diberikan ruang partsipasi dalam Musrenbang. Puncaknya tahun 2014 di bawah kepemimpinan Lurah Harry Agus Perdana, S.STP, mulai memberikan kesempatan bagi perwakilan dari Etnis Tionghoa untuk berpartisipasi dalam Musrenbang. Alasan dari Kelurahan Sukadamai mendorong Etnis Tionghoa untuk berpartisipasi dalam Etnis Tionghoa yang didasari; Pertama, memberikan hak yang setara bagi Etnis Tionghoa untuk ambil andil dalam Musrenbang. Kedua, menyerap ide-ide dari Etnis Tionghoa untuk kemajuan pembangunan Kelurahan
Sukadamai, Kecamatan Medan Polonia. Dan Ketiga, mendorong Etnis Tionghoa untuk berbaur dengan seluruh masyarakat Sukadamai dan melahirkan interaksi social.

Mengapa peneliti memilih Kelurahan Sukadamai, Kecamatan Medan Polonia sebagai lokasi penelitian? Ada beberapa faktor yang mendasari peneliti lokasi penelitian Kelurahan Sukadamai, Kecamatan Medan Polonia yakni; Pertama, karena jumlah penduduk Kelurahan Sukadamai, Kecamatan Medan Polonia mayoritas etnis Tionghoa. Kedua, karena peneliti menjadi bagian dari masyarakat Sukadamai. Sehingga peneliti akan lebih mudah untuk mendapatkan data-data dalam menyelesaikan penelitian ini.

\section{METODE PENELITIAN}

Jenis Penelitian ini adalah penelitian Deskriptif kualitatif, dalam penelitian deskriptif ini, peneliti hanya memberikan suatu gambaran secara sistematis, faktual dan akurat mengenai fakta-fakta yang sesuai dengan ruang lingkup judul penelitian. Metode penelitian yang digunakan dalam penelitian ini bertujuan untuk memberikan gambaran mengenai partisipasi masyarakat etnis Tionghoa dalam Musyawarah Perencanaan Pembangunan (Musrenbang) di Kelurahan Kamboja Sukadamai, Kecamatan Medan Polonia.

Dalam penelitian ini menggunakan teknik Purposive sampling, yaitu menentukan informan secara sengaja dengan pertimbanganpertimbangan tertentu. Dalam penelitian ini tidak mengenal populasi dan sampel melainkan informan, jumlah informan dalam penelitian ini adalah 5 tokoh masyarakat Tionghoa, 1 Lurah dan 2 Tokoh masyarakat/kepala lingkungan.

Sumber data primer, Merupakan sumber data yang diperoleh secara langsung dari sumber asli. Dalam halnya penelitian ini sumber data primer adalah Tokoh masyarakat Etnis Tionghoa, Kepala Lingkungan dan pemerintah kelurahan. Total yang menjadi informan sebagai data primer adalah 5 orang.

Data Sekunder, yaitu data merupakan data yang diperoleh secara tidak langsung melalui media perantara (diperoleh dan dicatat oleh pihak lain), yang pada umumnya berupa bukti, catatan-catatan yang telah tersusun dalam arsip (dokumenter), baik yang dipublikasikan atau tidak. Dalam halnya 
penelitian ini yang menjadi sumber data skunder adalah literature-literatur dan arsiparsip (dokumenter) yang ada di perpustakaanperpustakaan maupun kearsipan di Kelurahan Sukadamai, Kecamatan Medan Polonia.

Teknik pengumpulan data yang digunakan dalam penelitian ini adalah Observasi, wawancara dan studi pustaka. Observasi adalah pengamatan langsung ke lokasi penelitian yang dilakukan dengan memperhatikan, mempelajari dan mencatat berbagai hal yang dapat dijadikan objek penelitian, serta mengumpulkan data sekunder dari berbagai dokumen. Tujuan pendekatan observasi ini adalah untuk memahami berbagai situasi dan kondisi serta keterangan yang tercakup dalam dimensi partisipasi masyarakat etnist tionghoa dalam Musrenbang di Kelurahan Sukadamai Kecamatan Medan Polonia.

Wawancara, wawancara merupakan salah-satu metode pengumpulan data untuk mendapatkan informasi dengan cara bertanya langsung kepada informan (Simanjuntak \& Sosrodiharjo, 2014). Dalam hal penelitian ini, peneliti akan melakukan wawancara dengan tokoh/perwakilan masyarakat etnis tionghoa yang terlibat dalam Musrenbang tahun 2017. Selain itu, peneliti akan mewancarai pemerintahan Kelurahan Sukadamai termasuk Kepala Lingkungan. Pertanyaan-pertanyaan dalam wawancara secara garis besar akan menggali informasi dari informan yang berkaitan dengan proses musrenbang dan partisipasi masyarakat etnis tionghoa, serta bentuk-bentuk partisipasi masyarakat etnis tionghoa dalam Musrenbang Kelurahan Sukadamai Kecamatan Medan Polonia.

Studi Kepustakaan, Aktivititas pengumpulan berbagai jenis data sekunder yang dilakukan dengan cara mempelajari dan mengutip teori dari berbagai buku dan mempelajari dan mengutip data dari berbagai dokumen, serta mengutip informasi dari internet yang berkaitan dengan partisipasi masyarakat etnis tionghoa khususnya berkaitan dengan Musrenbang Kelurahan Sukadamai Kecamatan Medan Polonia.

Teknik analisis yang dipakai penelitian ini yaitu menggunakan analisis data kualititif. Menurut Bogdan \& Biklen analisis data kualitatif adalah upaya yang dilakukan dengan jalan bekerja dengan data, mengorganisasikan data, memilah-milahknya menjadi satuan yang dapat dikelola mensistesikannya, mencari dan menemukan pola, menemukan apa yang penting dan apa yang dipelajari, dan memutuskan apa yang diceritakan kepada orang lain (Moelong, 2011).

\section{HASIL PEMBAHASAN \\ Partisipasi Masyarakat Etnis Tionghoa Dalam Musrenbang Kelurahan Sukadamai Kecamatan Medan Polonia}

Musrenbang Kelurahan adalah forum dialogis antara pemerintah kelurahan dengan pemangku kepentingan lainnya, untuk mendiskusikan dan menyepakati program pembangunan yang dapat memajukan keadaan kelurahan. Musyawarah sebenarnya sudah mempunya pengertian yang sangat jelas yaitu suatu forum untuk merembungkan sesuatu dan berakhir pada pengambilan kebijakan/keputusan bersama. Dalam Musrenbang Kelurahan, pemerintah kelurahan dan komponen masyarakat bekerjasama memikirkan cara memajukan keadaan kelurahan melalui program pembangunan di Kelurahan.

Dalam musrenbang Kelurahan Sukadamai dihadari berbagai komponen yang berasal dari stake holder baik pemerintah maupun perwakilan masyarakat. Dari 50 peserta yang hadir, terdapat 20 peserta yang berasal dari etnis tionghoa. Masyarakat sangat antusias dalam mengikuti Musrenbang Kelurahan Sukadamai. Dari 70 undangan yang disebar, hanya 20 yang tidak hadir. Tentu tingkat partisipasi itu tinggi termasuk keterlibatan dari masyarakat etnis tionghoa yang hadir.

Argumen dari salah satu masyarakat Etnis Tionghoa yang hadir dalam Musrenbang menyatakan;

"Saya hadir dalam musrenbang, karena musrenbang sangat penting. Karena setahu saya Musrenbang merupakan forum musyawarah bersama pemerintahan kelurahan, tokoh masyarakat, tokoh pendidikan, tokoh kesehatan, tokoh agama, pemuda dan anggota masyarakat. Karena untuk menyepakati kesepakatan yang bermuara pada kebijakan di Kelurahan Sukadamai, keterlibatan masyarakat sangat penting"

Selain itu, warga etnis tionghoa juga punya argumen lain yang mendasari mengapa hadir dalam Musrenbang kelurahan Sukadamai 
seperti kutipan wawancara yang dilakukan peneliti;

"baru kali ini saya diundang dalam Musrenbang kelurahan Sukadamai. Selama ini kami (masyarakat etnis tionghoa) belum pernah diundang. Kami merasa dihargai dan merasa mempunyai hak yang sama seperti masyarakat asli lainnya untuk ikut dalam Musrenbang di kelurahan sukadamai."

Kemudian pernyataan lain juga disampaikan oleh masyarakat Etnis Tionghoa lainnya menyatakan bahwa ia hadir dalam Musrenbang, sebab menurutnya Musrenbang ini sangat penting untuk membahas programprogram apa saja yang akan dilaksanakan di kelurahan Sukadamai nantinya dan semoga sesuai dengan yang diharapkan. Dan disitulah proses perencanaan pembangunan kelurahaan sukadamai dirancang bersama masyarakat yang selanjutnya dengan meminta pendapat, saran, ataupun masukan dari masyarakat.

Peneliti kemudian mewancarai sekretaris kelurahan Sukadamai terkait partisipasi etnis tionghoa dalam musrenbang berikut petikannya;

"kami sangat bangga dapat melibatkan partisipasi masyarakat etnis tionghoa untuk mengikuti proses Musrenbang baik pra hingga evaluasi. Mereka terlibat dalam TPM-tim pamandu dan perwakilan masyarakat dalam Musrenbang Kelurahan. Tentu ini terobosan baru untuk meningkatkan partisipasi masyarakat Etnis Tionghoa di Kelurahan Sukadamai. Karena bagaimana pun, mereka adalah warga kami dan mereka berhak untuk ikut dalam proses pembangunan di Kelurahan Sukadamai".

\section{Proses Partisipasi Masyarakat Etnis Tionghoa Dalam Musrenbang Kelurahan Sukadamai Kecamatan Medan Polonia}

Partisipasi masyarakat merupakan keterlibatan masyarakat dalam pembangunan yang dinilai berdasarkan tahap perencanaan pembangunan, tahap pelaksanaan pembangunan, tahap pemanfaatan hasil pembangunan dan tahap evaluasi. Dalam penelitian ini yang berjudul Partisipasi Masyarakat Etnis Tionghoa Dalam Pelaksanaan Musrenbang Kelurahan Sukadamai Kecamatan Medan Polonia.
Beberapa tahapan proses Musrenbang di Kelurahan Kecamatan Medan Polonia yang mencakup;

a. Tahapan Pra Musrenbang

Kegiatan Musrenbang sangat panjang dan bukan hanya mempersiapkan teknis-teknis pelaksanaan Musrenbang saja seperti penyebaran undangan, pengadaan tempat dan komsumsi. Namun, kegiatan utama pra musrenbang yang dilakukan di Kelurahan Kecamatan Medan Polonia adalah menyiapkan substansi atau materi untuk menyusun rencana pembangunan kelurahan secara baik.

Tujuan Pra Musrenbang di Kelurahan Sukadamai Kecamatan Medan Polonia diantaranya;

a. Pengorganisasian Musrenbang terdiri atas kegiatan-kegiatan: 1). Pembentukan Tim Penyelenggara Musrenbang (TPM); 2). Pembentukan Tim Pemandu Musrenbang Kelurahan (3-4 orang); 3). Persiapan teknis pelaksanaan Musrenbang yaitu penyusunan jadwal dan agenda Musrenbang Kelurahan. Kedua, sosialisasi waktu pelaksanaan Musrenbang dan penyebaran undangan kepada peserta dan narasumber (H-7). Mengkordinir persiapan logistik (komsumsi, tempat, peralatan).

b. Pengkajian Kelurahan secara partisipatif yang terdiri dari kegiatan; 1). Kajian kondisi, permasalahan dan potensi kelurahan;2). Penyusunan data/informasi desa dari hasil kajian oleh tim pemandu.

c. Penyusunan draf rancangan awal RKP dan hasil kajian terdiri dari atas kegiatankegiatan; 1). Kajian ulang (review) dokumen RPJM Kelurahan Sukadamai dan hasil kajian kelurahan oleh TPM dan tim pemandu; 2). Kajian dokumen/data/informasi kebijakan program dan anggaran daerah oleh TPM dan tim pemandu; 3). Penyusunan draf rancangan awal RKP Kelurahan dengan mengacu pada kajian oleh TPM dan Tim Pemandu.

Perlu diketahui dalam tahapan pra Musrenbang ini, keterlibatan etnis tionghoa baik masyarakat umum maupun yang tergabung di TPM dan tim pemandu telah ikutserta. Sebagaimana kutipan wawancara dengan lurah mengatakan;

"kami sebagai pegawai kelurahan sukadamai kecamatan medan polonia, 
mempunyai komitmen yang tinggi untuk melibatkan masyarakat Etnis Tionghoa dalam musrenbang. Bukan hanya dalam pelaksanaan, tapi kami juga mengajak masyarakat Etnis Tionghoa ikut serta dalam forum-forum RT/RW dalam tahapan pra pelaksanaan Musrenbang Kelurahan. Kami juga memasukkan nama-nama beberapa Etnis Tionghoa dalam TPM maupun tim pemandu. Hal ini kami lakukan karena menyadari bahwa masyarakat di kelurahan sukadamai sebagian besar berasal dari Etnis Tionghoa".

\section{b. Tahapan Pelaksanaan Musrenbang Kelurahan}

Musrenbang Kelurahan Sukadamai Kecamatan Medan Polonia dilaksanakan pada tanggal 6 Februari 2017, pukul 10.00 WIB s/d selesai. Adapun peserta yang terlibat dalam Musrenbang ini terdiri dari perwakilan RT/RW, keterwakilan sektor ekonomi/kesehatan/pendidikan, kategori perwakilan kategori usia (tokoh pemuda/tokoh masyarakat), keterwakilan tiga unsur utama tata pemerintah (pemerintah kelurahan, swasta dan masyarakat umum), serta unsur organisasi masyarakat sipil di Kelurahan. Adapun total yang terlibat dalam Musrenbang di Kelurahan Sukadamai, Kecamatan Medan Polonia adalah 20 peserta. Dari 20 peserta yang terlibat, terdapat 8 peserta yang berasal dari Etnis Tionghoa. Tentu ini jumlah yang besar, karena sebelumnya mereka tidak terlibat dalam Musrenbang Kelurahan.

Prioritas yang dibahas dalam pelaksanaan Musrenbang Kelurahan Sukadamai, Kecamatan Medan Polonia sesuai dengan materi atau substansi yang dipersiapkan dalam tahapan pra Musrenbang, yakni; Pertama, menyusun rencana kerja pembangunan kelurahan sesuai tahun anggaran. Kedua, daftar permasalahan yang terjadi di Kelurahan Sukadamai. Ketiga, membahas dan menetapkan nama-nama yang mengikuti Musrenbang di tingkat Kecamatan Medan Polonia. Keempat, berita acara Musrenbang.

Proses Musrenbang Kelurahan Musrenbang Kelurahan Sukadamai, Kecamatan Medan polonia Meliputi;

1. Pembukaan

a. Acara dipandu oleh pembawa acara dengan kegiatan sebagai berikut;

b. Kata pembuka dan menyampaikan agenda Musrenbang c. Laporan dari ketua Musrenbang Kelurahan (Ketua TPM)

d. Sambutan dari Lurah dan sekaligus membuka acara Musrenbang secara resmi

e. Doa bersama

2. Membahas dan menetapkan tata tertib Musrenbang

Tata tertib ini dibuat untuk mengatur guna menyukseskan Musrenbang yang dijakankan. Dalam tatib ini mencakup teknis pelaksanaan musrenbang, hak dan kewajiban, tata cara penyusunan prioritas dan pengambilan keputusan, dan lain-lain.

3. Pemaparan dan diskusi panel dengan narasumber

Dalam hal ini, wakil masyarakat memaparkan mengenai gambaran persoalan kelurahan sukadamai kecamatan medan polonia berdasarkan hasil temuan kajian, yang dibagi berdasarkan urusan/bidang pembangunan kelurahan sukadamai kecamatan medan polonia. Ada 2 perwakilan yang memaparkan dalam musrenbang tersebut, 1 diantaranya berasal dari etnis tionghoa.

Setelah pemaparan dari wakil masyarakat, Lurah memberikan pemaparan mengenai; 1). Hasil evaluasi RKP Kelurahan yang sudah berjalan; 2). Kerangka prioritas program menurut RPJM Kelurahan; 3). Informasi perkiraan ADK dan sumber anggaran lain untuk tahun yang sedang direncanakan.

Dilanjut pemaparan dari pegawai kecamatan UPTKD/SPKD kecamatan mengenai kebijakan dan program prioritas program daerah di wilayah kecamatan. Setelah masingmasing pihak memaparkan materinya, kemudian terjadi diskusi atau dialog kepada masyarakat atau peserta yang hadir. Sebagaimana catatan dalam notulen rapat Musrenbang, salah-satu warga dari Etnis Tionghoa AL berpendapat dalam Musrenbag sebagai berikut;

"kelurahan Sukadamai begitu banyak tiap tahun bangunan-bangunan berdiri. Hal itu tentu kita ketahui berpengaruh pada pendapatan asli kelurahan. Namun, pembangunan juga perlu dikontrol dengan merawat kawasan-kawasan. Sebab, bukan rahasia umum lagi jika kota medan kerap mengalami bencana banjir karena hilangnya kawasan-kawasan hijau di Kota Medan". 
4. Pemaparan draf awal rancangan awal RKP kelurahan oleh TPM (Sekretaris kelurahan) dan tanggapan/pengecekan oleh peserta.

5. Kesepatakan kegiatan prioritas dan anggaran per bidang.

6. Musyawarah penentuan tim delegasi kelurahan

7. Penutupan dengan penandatanganan berita acara musrenbang dan penyampaian kata penutup oleh ketua TPM/pemandu.

c. Tahapan Pasca Musrenbang Kelurahan Sukadamai Kecamatan Medan Polonia

Rapat Kerja Tim Perumus hasil Musrenbang Kelurahan; 1).Penerbitan SK Lurah untuk tim delegasi kelurahan; 2). Penyusunan untuk daftra prioritas masalah kelurahan untuk disampaikan di Kecamatan Medan Polonia. 3). Penyusunan RKP Kelurahan samapai menjadi SK Lurah.

Pembekalan Tim Delegasi Kelurahan oleh TPM (termasuk tim pemandu) agar; 1). Menguasai data/informasi dan penjelasan mengenai usulan yang akan dibawa tim delegasi Musrenbang kecamatan; 2). Penguatan kemampuan lainnya (wawasan, teknik, komunikasi, persentasi).

Penyusunan anggaran pendapatan dan belanja Kelurahan (APB Kelurahan) dengan mengacu pada dokumen rencana kerja pembangunan Kelurahan (RKP Kelurahan).

\section{Faktor Pendukung Masyarakat Etnis Tionghoa Berpartisipasi Dalam Musrenbang Kelurahan Sukadamai Kecamatan Medan Polonia}

Meningkatnya partisipasi masyarakat Etnis Tionghoa dalam Musrenbang kelurahan Sukadamai Kecamatan Medan Polonia meliputi;

1. Kemauan untuk berpartisipasi

Munculnya nilai-nilai eksistensi masyarakat etnis tionghoa untuk berpartisipasi dalam pembangunan di Kelurahan Sukadamai, Kecamatan Medan Polonia. Selama ini mereka merasa tidak dilibatkan dan kecenderungan politik diskriminasi yang bertedensi rasial membuat mereka terpinggirkan.

Adanya upaya untuk meningkatkan kualitas pembangunan di Kelurahan Sukadamai kecamatan Medan Polonia.
Adanya nilai kebersamaan untuk menyelesaikan masalah dan mencapai tujuan pembangunan di kelurahan Sukadamai.

Adanya kesadaran sebagai warga negara yang mempunyai hak dan kewajiban atas pembangunan.

2. Kemampuan untuk Berpartisipasi

Masyarakat Etnis Tionghoa merasa mempunyai kemampuan baik dari segi pengetahuan maupun aspek ekonomi sebagai referensi untuk merumuskan dan menetapkan kebijakan pembangunan di Kelurahan Sukadamai, Kecamatan Medan Polonia.

Kemampuan untuk memecahkan masalah dengan kesempatan yang diberikan oleh pemerintah kelurahan dan tentunya dijamin oleh perundang-undangan.

3. Kesempatan bagi Masyarakat untuk berpartisipasi

Beberapa kesempatan yang dimaksud adalah;

a. Kemauan pemerintahan kelurahan sukadamai untuk melibatkan masyarakat Etnis Tionghoa dalam perencanaan, pelaksanaan dan evaluasi pembangunan

b. Kesempatan untuk memperoleh informasi pembangunan

c. Kesempatan untuk memanfaatkan mobilisasi sumber daya alam maupun manusia dalam pembangunan

d. Kesempatan untuk mengembangkan kehidupan bermasyarakat dan bernegara bagi masyarakat Etnis Tionghoa di kelurahan Sukadamai

\section{Bentuk-Bentuk Partisipatif Masyarakat Etnis Tionghoa Dalam Musrenbang Kelurahan Sukadamai Kecamatan Medan Polonia}

Berbagai kegiatan etnis tionhoa dalam Musrenbang di Kelurahan Sukadamai telah ditunjukkan. Maka peneliti akan merangkum ke beberapa dimensi sebagai bentuk nyata partisipasi masyarakat Etnis Tionghoa dalam Musrenbang Kelurahan Sukadamai Kecamatan Medan Polonia.

\section{Proses Pengambilan Kebijakan}

Proses pengambilan keputusan yang dimaksudkan disini adalah tahap-tahap dalam membuat suatu keputusan yang akhirnya akan ada pemilihan alternatif kesepakatan terbaik dari beberapa masukan atau saran yang 
ditampung. Proses pengambilan keputusan dapat dilihat dan dimulai dari indikator.

a. Tahap musyarawah dalam perencanaan pembangunan

Tahap pertemuan dalam Musrenbang memiliki beberapa fase tingkatan yaitu, Musrenbang RT/RW, Musrenbang Kelurahan, Musrenbang Kecamatan, Musrenbang Kota, Musrenbang Provinsi, dan terakhir Musrenbang Nasional. Sebelum sampai ke Musrenbang tingkat Kelurahan proses pertama dalam pengambilan keputusan tingkat awal akan dilakukan ditingkat RT lalu berlajut ke tingkat RW untuk dirembug ulang, lalu masuk kedalam Musrenbang tingkat Kelurahan. Dalam Musrenbang RT musyawarah dilakukan bersama masyarakat yang ada diderahnya, dalam Musrenbang RW musyawarah dilakukan bersama para RT yang bersangkutan dengan RW tersebut, dan dalam Musrenbang Kelurahan musyawarah dilakukan bersama seluruh perangkat RT dan RW serta stakeholder lainnya. Dalam penelitian ini peneliti hanya melakukan penelitian sampai batas Musrenbang tingkat Kelurahan.

Berdasarkan hasil penelitian di lapangan, diadakan mussyawarah di tingkat RT. Mereka membahas berbagai masalah, potensi sumber daya alam dan manusia di lingkungan RT serta aspirasi-aspirasi untuk dibawa dalam Musrenbang Kelurahan Sukadamai. Dalam musyawarah di tingkat RT, masyarakat Entis Tionghoa ikut terlibat. Sebagaimana petikan kutipan dari hasil wawancara peneliti terhadap warga Etnis Tionghoa AL yang mengikuti musyawarah tingkat desa;

" ketika pak RT mengumumkan diadakannya musyawarah tingkat RT dalam pra Musrenbang Kelurahan, kami (Etnis Tionghoa) mempunyai kesadaran untuk terlibat di dalamnya. Sebab kami mempunyai hak dan kewajiban yang setara dengan warga lain untuk ikut dalam proses pembangunan di Kelurahaan khususnya di RT kami. Kami ingin menyampaikan gagasan atau aspirasi kami untuk diperjuangkan menjadi agenda pembangunan (RKP) di kelurahan Sukadamai".

Selain itu, peneliti juga mewancarai warga Etnis Tionghoa EC yang ikut dalam musyawarah tingkat RT. Dia mengemukakan kepada peneliti;

"saya belum pernah ikut proses musyawarah untuk membicarakan perencanaan pembangunan di kelurahan sukadamai. Saya ingin berpartisipasi dalam musyawarah ini agar saya dapat mempelajari sekaligus memberikan pendapat akan rencana pembangunan di kelurahan Sukadamai ke depan".

Selain membahas aspirasi akan ide pembangunan di kelurahan Sukamadai, musyawarah di tingkat RT juga memilih perwakilan sebagai peserta Musrenbang Kelurahan Sukadamai. Perwakilan dari tingkat RT sebagian menunjuk warga Etnis Tionghoa sebagai perwakilan RT-nya.

b. Mengumpulkan dan Mengundang

Proses mengundang dalam sebuah pertemuan perlu dilakukan sebagai bukti bahwa benar ada pertemuan yang akan dilaksanakan. Undangan merupakan sebuah kejelasan yang menerangkan waktu serta tempat untuk mengumpulkan masyarakatnya. Undangan juga menjadi simbol bahwa petugas menginginkan masyarakatnya hadir dalam pertemuan tersebut. Untuk itu Peneliti disini ingin melihat apakah benar dilakukan proses pembagian undangan dalam mengadakan pertemuan Musrenbang Kelurahan dan apakah pihak Kelurahan juga mengundang masyarakat Etnis Tionghoa.

Berdasarkan hasil wawancara peneliti dengan Lurah menjelaskan bahwa lurah memberikan intruksi agar memberikan undangan. Bahkan salah-satu RT di Kelurahan Sukadamai berasal dari Etnis Tionghoa. Beliau secara pro aktif menyebarluaskan undangan kepada warganya untuk menghadiri musyawarah di tingkat RT.

2. Menentukan Kebutuhan

Menentukan kebutuhan yang dimaksudkan disini adalah suatu proses penyampaian saran, ide serta gagasan dari masyarakat kepada pegawai guna terciptanya perencanaan pembangunan yang di inginkan masyarakat. Menentukan kebutuhan dapat dilihat dari indikator:

a. Kehadiran dalam Musrenbang Kelurahan untuk mengumpulkan ide/aspirasi

Musyawarah perencanaan pembangunan (Musrenbang) diadakan agar masyarakatnya dapat menyampaikan ide - ide serta pendapatnya tentang pembangunan diderahnya. Didalam musrenbang ini akan terjadi feedback antara masyarakat dengan pemerintah. Tanpa adanya keterlibatan masyarakat, perencanaan pembangunan yang 
terjadi tidak akan menjadi pembangunan yang ideal.

Karena pembangunan yang ideal adalah pembangunan yang sesuai dengan keinginan masyarakat. Oleh karena itu partisipasi kehadiran masyarakat penting guna mensukseskan rapat Musrenbang. Didalam indikator ini peneliti akan melihat setelah proses pembagian undangan apakah masyarakat Etnis Tionghoa menghadiri rapat Musrenbang yang diselenggarakan oleh pihak Kelurahan.

Berdasarkan pendapat pihak Kelurahan sudah memberikan kesempatan untuk masayarakat Etnis Tionghoa yang menjabat sebagai RT dan RW untuk hadir dalam proses Musrenbang, namun masyarakat Etnis Tionghoa yang diundang tidak semuanya hadir, dikarenakan kesibukan mereka dalam pekerjaan. Berdasarkan pendapat pihak Kelurahan sudah memberikan kesempatan untuk masayarakat Etnis Tionghoa yang menjabat sebagai RT dan RW untuk hadir dalam proses Musrenbang, namun masyarakat Etnis Tionghoa yang diundang tidak semuanya hadir, dikarenakan kesibukan mereka dalam pekerjaan.

Sebagaimana kutipan wawancara dengan EC masyarakat Etnis Tionghoa mengungkapkan;

"dalam forum Musrenbang Kelurahan, pemerintah kelurahan memberikan kami (Etnis Tinghoa) untuk mengemukakan pendapatnya secara bebas. Kami tidak dihalang-halangi dalam memberikan pendapat ataupun masukan terkait rencana pembangunan di Kelurahan Sukadamai".

b. Menentukan kebutuhan rencana pembangunan

Musyawarah perencanaan pembangunan (Musrenbang) diadakan untuk menentukan kebutuhan perencanaan pembangunan. Dalam proses menentukan perencanan pembangunan ini sangat perlu ide - ide atau pendapat masyarakat guna menentukan pembangunan yang akan berguna bagi kepentingan masyarakat umum serta perbaikan pembangunan yang telah rusak ataupun ditingkatkan lagi kegunaannya. Dari indikator ini maka peneliti ingin melihat bagaimanakah partisipasi masyarakat Etnis Tionghoa dalam menyalurkan ide - ide atau pendapat dalam menentukan kebutuhan perencanaan pembangunan.

Berdasarkan wawancara peneliti, masyarakat Etnis Tionghoa diundang dalam musyawarah di tingkat RT. Masyarakat etnis tionghoa diberi kesempatan yang sama seperti warga lainnya untuk menyampaikan gagasan, ide terkait usulan-usulan rencana pembangunan di kelurahan Sukadamai khususnya di wilayah masih-masih RT.

3. Menunjuk Tujuan dan Prioritas

Menunjukkan tujuan dan prioritas yang dimaksudkan disini adalah suatu proses kesepakatan bersama antara pegawai dan masyarakat dalam setiap kegiatan musrenbang yang dimana hasil akhirnya demi tujuan serta kepentingan bersama. Menunjukkan dan prioritas dapat dilihat dari indikator :

a. Menentukan kebutuhan yang harus dibutuhkan

Dalam proses terakhir di Musrenbang Kelurahan yaitu menentukan prioritas pembangunan yang akan diusulkan kembali ke Musrenbang Kecamatan. Dalam menentukan prioritas ini biasanya pihak Kelurahan akan berdiskusi untuk menentukan 1 aspek dari 3 kelompok pembangunan yang akan di prioritaskan. Dalam indikator ini peneliti ingin melihat prioritas yang di pilih serta bagaimana cara menentukannya.

Berdasarkan hasil penelitian, adanya upaya sosialisasi dan melibatkan masyarakat Etnis Tionghoa dari mulai fase persiapan hingga evaluasi Musrenbang. Sebagaimana yang sudah dijelaskan, agenda musrenbang sendiri membutuhkan persiapan panjang mulai dari pembentukkan tim penyelenggara musrenbang kemudian tim pemandu musrenbang desa. Berikutnya penyiapan teknis pelaksanaan musrenbang desa meliputi penyusunan jadwal dan agenda musrenbang desa, kemudian mengumumkan dan menyebarkan undangan minimal tujuh hari sebelum hari $\mathrm{H}$.

Sebelum penyusunan draf rancangan awal RKP Kelurahan terlebih dahulu dilakukan pengkajian Kelurahan secara partisipatif yang berisi kajian kondisi, permasalahan, dan potensi kelurahan bersama warga masyarakat kemudian penyusunan data/informasi kelurahan dari hasil kajian oleh tim pemandu. Untuk mendapatkan hasil musrenbang yang 
akurat dan sesuai dengan kebutuhan desa diperlukan pengetahuan tentang pelaksanaan musrenbang itu sendiri dan kefokusan baik dari tim penyelenggara maupun tim pemandu untuk menjalankan musrenbang sesuai dengan prosedur. Pelaksanaan program merupakan tahapan kegiatan yang dimulai dari tahap perencanaan sampai dengan tahap penyelesaian kegiatan. Proses perencanaan dan pengambilan keputusan dalam program pembangunan kerap kali dilakukan dari atas kebawah. Rencana program pengambangan masyarakat biasanya dibuat ditingkat pusat dan dilaksanakan oleh instansi propinsi dan kebupaten. Masyarakat sering kali diikutkan tanpa diberikan kesempatan untuk memberikan masukan. Hal ini biasanya disebabkan adanya anggapan bahwa untuk mencapai dalam pembangunan bagi masyarakat tidak mempunyai kemampuan untuk menganalisa kondisi dan merumuskan persoalan serta kebutuhan-kebutuhannya. Dalam hal ini masyarakat selalu ditempatkan pada posisi yang membutuhkan bantuan dari luar. Program yang dilakukan dari atas kebawah sering tidak berhasil dan kurang memberi manfaat kepada masyarakat, karena masyarakat kurang terlibat sehingga mereka merasa kurang bertanggungjawab terhadap ketergantugan yang pada gilirannya akan lebih menyusahkan masyarakat dari pada menolongnya.

Tahap perencanaan dimulai dengan penggalian gagasan yang dilakukan oleh ketuaketua RT kepada kelompok-kelompok masyarakat yang diwakilinya. Kelompokkelompok masyarakat tersebut tersebar masyarakat etnis Tionghoa. Mereka mendapatkan penjelasan mengenai musrenbang dan kewajiban untuk turut berperan serta menyampaikan aspirasinya. Untuk efisiesi maka kegiatan pengalian gagasan dilakukan dengan memanfaatkan pertemuan rutin yang sudah ada (formal maupun informal). Dalam pertemuan RT tersebut, warga membahas apa yang menjadi gagasangagasan kegiatan untuk memenuhi kebutuhannya. Gagasan-gagasan tersebut selanjutnya dimasukkan dalam sebuah daftar gagasan untuk dibawa ke musyawarah desa. Musyawarah Kelurahan adalah suatu forum pertemuan masyarakat desa yang bertujuan untuk membahas seluruh usulan kegiatan hasil dari penggalian gagasan diringkat RT.
Selanjutnya dilakukan penyusunan proposal yang merupakan kegiatan dengan tujuan untuk menguraikan secara tertulis rencana dari hasil musyawarah di Kelurahan. Selanjutnya proposal tersebut dibawa ke forum musyawarah antar kelurahan di tingkat kecamatan yang bertujuan untuk membahas, memilih serta memutuskan dan menetapkan peringkat usulan kegiatan dari masing-masing kelurahan.

b. Memutuskan dengan keputusan bersama

Keputusan akhir dengan disetujui oleh seluruh pihak penting bagi berjalannya sebuah pertemuan Musrenbang. Karena tanpa persetujuan yang disepakati oleh seluruh peserta maka akan menimbulkan pro dan kontra yang menyebabkan perselisihan. Oleh sebab itu Musrenbang ini diadakan guna memberitahu masyarakat tentang pembangunan yang kan dibangun agar tidak ada konflik yang terjadi dimasyarakat kedepannya. Dari indikator ini peneliti ingin mengetahui apakah segala keputusan akhir dalam Musrenbang Kelurahan teah disetujui oleh peserta.

Berdasarkan hasil wawancara peneliti dilapangan dapat disimpulkan bahwa masyarakat ada yang pro dan kontra dalam proses Musrenbang tingkat RT. Ada yang setuju perencanaan pembangunan di tentukan oleh hasil survey yang dilakukan oleh perwakilan masyrakat karna lebih efektif, dan ada yang tidak setuju dengan alasan suara masyarakat tidak semuanya sama.

Maka untuk memperoleh gambaran yang jelas tentang partisipasi apa sajakah yang dilakukan oleh masyarakat Etnis Tionghoa pada proses Musyawarah Perencanaan Pembangunan (Musrenbang) di Kelurahan Sukadamai Kecamatan Medan Polonia, disini peneliti akan memaparkan mengenai jenis jenis partisipasi menurut Keith Davis dalam (Sastropoetro, 1986:16).

Jenis-jenis partisipasi tersebut adalah :Partisipasi berupa pikiran (psychological participation), Partisipasi yang berupa tenaga (Physical Participation), Partisipasi yang berupa tenaga dan pikiran (physical and psychological participation), Partisipasi yang berupa keahlian (participation with skill), Partisipasi yang berupa barang (material participation), Partisipasi yang berupa uang (money participation), yang dilakukan oleh masyrakat ethnis Tionghoa dalam proses 
Musrenbang yaitu partisipasi berupa pikiran (psychological participation) dimana pada saat melakukan Murenbang di Kantor Kelurahan Sukadamai beberapa masyarakat Etnis Tionghoa yang menjabat sebagai RT/RW ada yang menyumbangkan ide atau pendapatnya, dan partisipasi berupa barang (material participation) serta uang (money participation) jika ada pelaksanaan program.

Demikian juga yang diuraikan oleh Arnstein terdapat delapan (8) tangga partisipasi dari paling rendah hinngga tertinggi diantaranya; Pertama, Manipulation Merupakan keterlibatan dan peran masyarakat tidak ada sama sekali, dan kekuasaan berada ditangan pemerintah sepenuhnya. Kedua, Therapy Pemerintah mengatur segala sesuatunya, sehingga masyarakat merupakan obyek program sehingga tidak ada partisipasi. Ketiga, Informing Pada tingkatan ini, masyarakat mulai memperoleh gambaran mengenai pelaksanaan program dari pemerintah, namun tetap belum berperan serta aktif dan terlibat dalam pelaksanaan program.

Keempat, Consultation Pada tingkatan ini, mulai terlihat adanya saling tukar informasi antara pihak satu dengan pihak lainya, yang memungkinkan katerlibatan masyarakat dalam satu program. Kelima, Placation Pada tingkatan ini masyarakat yang ikut terlibat dan berpartispasi dalam program akan mendapatkan imbalan berupa plakat. Keenam, Partnership. Merupakan tingkatan partisipasi yang ideal, pemerintah dan masyarakat memiliki kedudukann yang sama dalam tahapan pelaksanaan program. Ketujuh, Delegated Power. Pada tingkatan ini, masyrakat mulai diberikan kekuasaan, sehingga kedudukan pemerintah berada dibawah rakyat. Kedelapan, Citizen Control. Pada tingkatan ini partisipasi masyarakat memegang kekuasaan tertinggi secara penuh dan sebagai akibatnya muncul kegiatan - kegiatan yang menjurus anarki.

Berdasarkan data dan fakta dari penelitian ini, peneliti menilai bahwa partisipasi masyarakat etnis tionghoa dalam Musrenbang Kelurahan Sukadamai, Kecamatan Medan Polonia telah masuk tahap partisipasi keenam yakti Partnership. Karena dapat dilihat, begitu tingginya keterlibatan masyarakat etnit tionghoa dalam setiap fase persiapan hingga evaluasi dalam Musrenbang Kelurahan Sukadamai, Kecamatan Medan Polonia. Demikian juga berbagai bentuk atau dimensi yang menunjukkan partisipasi masyarakat etnis tionghoa dalam Musrenbang.

\section{SIMPULAN}

Proses Musrenbang Kelurahan Sukadamai Kecamatan Medan Polonia terdiri dari Pra- persiapan (pengorganisasian Musrenbang, pengkajian, penyusunan draft rancangan awal RKP), Pelaksanaan (pembukaan, membahas tata tertib, pemaparan dan diskusi panel narasumber, pemaparan draft awal rancangan RKP dan tanggapan peserta, kesepakatan/keputusan, menentukan tim delegasi kelurahan) dan Penutupan (menandatangani berita acara Musrenbang). Dalam setiap tahapan ini, masyarakat Etnis Tionghoa terlibat aktif.

Apabila merujuk pikiran Arsntein dalam tingkatan partisipasi, peneliti menilai bahwa partisipasi masyarakat Etnis Tionghoa dalam Musrenbang Kelurahan Sukadamai, Kecamatan Medan Polonia telah masuk tahap partisipasi keenam yakti Partnership. Hal ini dapat dilihat dalam bentuk stuktur TPM dan Tim Pemandu Musrenbang, kehadiran sebagai peserta dalam pelaksanaan Musrenbang dan musyawarahmusyawarah di tingkat RT, pengambilan kebijakan, serta mengemukan pendapat. Maka jika merujuk pikiran Keith Davis yang menjelaskan tentang bentuk-bentuk partisipasi masyarakat, maka Etnis Tionghoa dalam Musrenbang Kelurahan Sukadamai Kecamatan Medan polonia meliputi; pikiran, tenaga, keahlian, barang dan uang.

\section{DAFTAR PUSTAKA}

Akbar, (2018). Partisipasi Masyarakat Dalam Perencanaan Pembangunan di Desa Jatimulua Kabupaten Boalemo. Jurnal Ilmu Administrasi, 6(2).

Arnstein, S. (1969). A Ladder of Citizen Participation, 35(4):216-224

Darmila, L. Ivanna, J. \& Iqbal, M. (2019) Perilaku Partisipasi Politik Masyarakat Desa Gunung Tua Tonga pada Pemilihan Bupati/Wakil Bupati Tahun 2013. PERSPEKTIF, 8 (2): 58-71.

Karwur, E Siska. (2016). Partisipasi Masyarakat dalam Pembangunan di Desa Pinamorongan Kecamatan Tareran. Jurnal Eksekutif, 1(7).

Kusmanto, H., (2013). Peran Badan Permusyawaratan Daerah dalam Meningkatkan Partisipasi Politik 
Masyarakat, JPPUMA: Jurnal Ilmu Pemerintahan dan Sosial Politik UMA (Journal of Governance and Political UMA), 1 (1): 41-47.

Lubis, I. (2010). Orang Pribadi Dan Orang Asing Salemba Empat. Jakarta.

Mahmud, A.A. (2013). Ekonomi Zakat; Sebuah Kajian Moneter dan Keuangan Syari. Yogyakarta: Pustaka Pelajar.

Moleong, L.J. (2011). Metodologi penelitian kualitatif. Bandung: Remaja Rosadakarya.

Mulyadi, Mohhamad. (2012). Partisipasi Masyarakat dalam Pembangunan Masyarakat Desa. Jurnal Studi Komunikasi dan Media, 16 (1):71-80

Sastropoetro, S. (1986). Partisipasi Komunikasi, Persuasi, dan Disiplin dalam. Pembangunan Nasional. Sosiologi Pembangunan. Bandung

Simanjuntak, A.B. \& Sosrodiharjo, S. (2014). Metode Penelitian Sosial, edisi revisi. Jakarta: Pustaka Obor.

Suharyanto, A., (2014). Partisipasi Politik Masyarakat Tionghoa dalam Pemilihan Kepala Daerah, JPPUMA: Jurnal Ilmu Pemerintahan dan Sosial
Politik UMA (Journal of Governance and Political UMA), 2 (2): 166-175

Suharyanto, A.,_2016) Surat Kabar Sebagai Salah Satu Media Penyampaian Informasi Politik pada Partisipasi Politik Masyarakat, Jurnal Administrasi Publik, 6 (2): 123-136.

Surbakti, R. (1992). Memahami Ilmu Politik (Edisi Cet.1). Jakarta: Grasindo.

Tan, F. (2012). Perencanaan Pembangunan Teori dan Aplikasi. Padang: Universitas Andalas Press.

Zega, M.A. Muda, I. Batubara, B.M. \& Suharyanto, A. (2018). Pengaruh Program Rumah Pintar Pemilu Terhadap Partisipasi Politik Masyarakat Pada Kantor Komisi Pemilihan Umum Kota Medan, PERSPEKTIF, 7 (2): 60-65.

Permendagri No.66 Tahun 2007 Tentang Perencanaan Desa

UU No. 32 Tahun 2004 Tentang Pemerintahan Daerah

UU No.6 Tahun 2014 Tentang Desa

UU No. 25 Tahun 2004 Tentang Sistem Perencanaan Pembangunan Nasional 